\title{
Surkhet
}

\section{Binary Opposition Between Arrogance and Patience in Owenson's The Missionary: An Indian Tale}

\author{
- Narayan Prasad Ammai
}

\begin{abstract}
"The Missionary: An Indian Tale" by Sydney Owenson (1811) a remarkable novel written in the backdrop of Spanish-Portuguese conflict in India, a haunting tale of cultural encounter and trans-racial romance set in early colonial India, deals with the theme of binary opposition between arrogance and patience. The Missionary focuses on the binary opposite relationship between Hilarion, a Portuguese missionary to India and Luxima, an Indian prophetess. Hilarion in the novel is presented as a colonizer who seems to be proud on his religion and intends to transform Luxima into Christian from Hindu whereas Luxima's patience is privileged. Both are aristocratic, devoted to their religions, and biased against other cultures. The primary objective of this study is to analyze how the state of binary opposition between Hilarion's arrogance and Luxima's patience exists. The focus of this study is what made Hilarion to be converted in front of Luxima who was supposed to convert her. Owenson is saying that it is the subjectivity of Luxima that gets transferred to Hilarion but not vice versa. By valorizing Luxima's subjectivity over Hilarion, the writer foregrounds the hidden value of the Hindu culture that gives emphasis not only upon the reason rather puts equal space for emotion. For this purpose the concepts of John Whale and Michael J. Franklin in used as a basic tool of textual analysis to prove its hypothesis.
\end{abstract}

Key words: Missionary, transformation, arrogance, patience, religion, colonialism

\section{Introduction}

The writer in the novel The Missionary: An Indian Tale (1811), brings into light the arrogance of the colonizer that is committed in Christianizing the so called uncivilized and barbaric Indians who presents himself as a man of reason while the Indians as the people full of emotions. This novel was written when there was heated debate among the authorities of the East India Company (EIC) about the missionary activity whether there should be religious intervention or not, deals with the impression 
against the missionary activity set in the seventeenth century missionary culture. During colonization, the West regarded India as a female "India is characterized as an abused woman; the source of her fecundity cruelly mutilated or cauterized, simultaneously spoiled and despoiled" (Franklin, pp. 54-55) and behaved with them as barbaric, uncivilized and superstitious people and claimed themselves as civilized humans and it was their responsibility to educate and civilize the barbaric Indians. With this mind set of the West, they started to feminize and colonize the Indians. Though their overtly declared mission was to educate and civilize the Indians but actually their eyes were on the massive property of India. The contemporary writings also reflect the interest of colonizers towards Indian property as "The throne was composed of gold, pearl, and brilliants..." (Franklin, p. 1). It was because their main interest was in the property than civilizing Indians. They found it easy to forward their civilizing mission through the loopholes of the Indian dominant religion: Hinduism. But, it brought about debates that whether India should be ruled from Indian way of life or from western world view. And this book is an attempt of Owenson that deals with the binary opposition between the arrogance of the colonizer called Hilarion and the patience of the Hindu priestess named Luxima.

The Missionary is a Portuguese noble of royal descent and a Franciscan monk named Hilarion who like other colonizers is fired with the enthusiastic zeal to convert others into Christianity, regards his religion as civilized, masculine and better than Hindu or Muslim. His attitude towards Hinduism reflects Western claims of ascendancy over the East. He claims
Luxima's religious beliefs as idolatrous are wrong and he imposes his so called truthful religion upon her. His morally superior attitude towards the Indians reflects his conceptualization of Hindus and Christians as falling into binary oppositions of East and West; immoral and moral; antiquated and modern; and male and female. Luxima, on the other hand, goes through the motions of conversion but she never gives up her commitment to Brahma, a fact of which Hilarion understands about her faith. She gets transferred into Christianity not because she has lost her faith on her Hindu religion but she is extremely attracted to Hilarion and it was justified when "... she shrieked, and called upon "Brahma!" -Brahma! Brahma! ..." (Owenson, p. 261). And Luxima demonstrates a profound commitment to her religious identity, performing rituals that link an oppressed past with a liberated future. Ultimately, the sympathy of the readers goes to Luximma.

Frances Botkin discusses this novel in terms of failed missionary project of religious transformation of the Portuguese colonizer during colonial India. The missionary himself who aimed to convert all the barbaric Indians is converted by the subjectivity of the heroine of the novel called the priestess Luxima. He surrenders in front of her religious creed and is also protected by that priestess from his inquisitor officers whom he had wanted to protect from the so called barbaric Sati culture of Hindu after the death of her lover.

In fact, Hilarion, the Missionary who travelled India for the purpose of converting the primitive Indians from the barbaric Hindu religion to the so called modern and civilized Christianity gets highly influenced by the subjectivity of Luxima "...he said, "My friend, my heart is deeply 
touched by your generous sympathy: ... but I belong to a religion whose sprit is to save, and not to destroy..." (Owenson, p. 240). And Luxima who was supposed to be converted into Christianity exclaimed that "Praise be to Vishnu! Who still protects those who are pure in heart, even though their hands are polluted!" (Owenson, p. 71). Thus, the Christianity arrogance and Hindu's patience's binary opposition becomes the theme of the novel where Luxima's patience is privileged throughout the novel. The researcher in this paper aims to analyze this binary opposition in terms of Hilarion's religious enthusiastic zeal to transfer others into Christianity which finally changes into the emotional zeal. And Luxima's patience in her Hindu religion remains unconverted until her death. Rather she converts him to give up his arrogance of his religion and colonial project and gives mixed preaches on both religions in the final days of his life. Along with this binary opposition, the researcher attempts to interpret it not from Saidian notion of negative representation of East but from positive notion of representation of East as the nature of the course.

\section{Analysis}

In this novel Luxima, the Hindu priestess is not speechless. Owenson gives voices to the patience of Luxima. When she falls on Hilarion's hand, she becomes a driving force to transfer his subjectivity. Thus, his arrogance of transferring her into Christian in true sense cannot be achieved rather he is transformed. This shows that there is both way impact of East to West and West to East. The romantic writers represent this impact in negative line such as Tim Fulford presents the alternative, negative aspects of Eastern influence, one which threatens and infects, albeit this time through the psychic agency of dreams. The East as a nexus of fears of despotism, corruption, effeminacy and infection..." (p.45). It means that "East can modify as well as corrupt West. Diseases came from east to Britain. Exotic food, missexual behavior, opium, etc. came to west from east" (Pandey Lecture).

Luxima is not an easy woman to be converted. She is one with the divinity. She proclaims, "I am myself become a part of the Divinity" (Owensonp.153) and "I adore the effulgent power, in whose luster I now shine, and of which I am myself an irradiated manifestation" (Owenson, p. 82). So, it seems impossible for him to convert her, but mistakenly, he believes he has done it which is just his hypocrisy. His hypocrisy continues. When he is about to be burnt down by the Christian Officers for his heresy and seduction of Luxima, she comes up and springs upon the pile exclaiming, "My beloved, I come!-Brahma receive and eternally unite our spirits!" (Owenson, p. 260). The Missionary introduces sati as Luxima's decision rather than imposed behavior of her community upon her by the elders. In fact, Luxima has expressed several times her wish in front of Hilarion to die with her lover in the novel when she sees him on the pyre; she calls out to Brahma to eternally unite their spirits. Knowing this, Hilarion's religious zeal converts into emotional zeal. He seems to have been unable to understand the culture of Sati in Hindu which he wants to change it saying it a barbaric culture. He does not know that sati is voluntary in this culture which is in practice since "Vedic times" (Franklin,p. 22). Though, till now, he believes that he has converted her and made her free from sati, actually it is not so. The word Brahma and 
her attempt of sati suggest that she is still a true Hindu. She springs into the pyre to prove that she is still a devoted Hindu woman who sacrifices herself in love of her man voluntarily. She does it not by compulsion as the Westerners thought. By this act, she rather saves him from the hand of the white Christian Inquisitors; moreover, she unites the Hindus against the Christians. About his victimized status, Franklin writes, "Owenson ends her novel with the auto$d e-f e$ of the Christian Inquisition, the intended victim of the flames being her hero, Hilarion" (p. 193). Hilarion, who is thinking of saving Indian woman from sati, has to be saved by her. Hilarion in the novel said "...but here, who is there to assist me" (Owenson, p. 70). And he added in a soft voice, "And thou hastsaved its life" (Owenson, p. 70).

Self-convinced with this false assumption, he puts great efforts to attract Luxima into his mission but ironically he is himself attracted. In front of her extraordinary attraction, he "had not the power to follow, nor to address her: he crossed himself, and prayed" (Owenson, p. 62). Here, Hilarion tries to prove himself that religious enthusiasm is also the enthusiasm of reason. But there is the gap between religious enthusiasm and sexual enthusiasm. He loses his reason of religiosity and gets trapped into sensibility by her erotic attraction. He expresses love and so does she. But her love is on the humanitarian ground not on the ground that she accepts him as a religious father. In her influence on him, Barbara writes, "Although he journeys to India to convert the subcontinent to Christianity, he comes under Luxima's influence instead and is converted to her humanitarian dispensation" (p. 207). Seemingly, she adopts Christianity but not by heart.
Owenson in her novel claims that there is conflict in Hilarion's arrogance and Luxima's patience:

As he spoke, he fell prostrate and almost lifeless on the earth: for two days no food had passed his lips; for two nights no sleep had closed his eyes; passion and honor, religion and love, opposed their conflicts in his mind; nature sunk beneath the struggle, and he lay lifeless at the feet of her who had forever destroyed the tranquility of his conscience and rendered valueless the sacrifices of his hitherto pure, sinless, and self-denying life. (p. 146).

In the above passage Owenson means to say that if we look at the British cultural trends of colonizers in reference to The Missionary: An Indian Tale, it is always Hilarion who is depicted as rational and engaged in civilizing mission is in the conflicts of passion and honour. It is because he does not believe in co- existence of both passion and honour but Luxima is not hurt by this dualistic view because she believes in dualistic view as Hinduism asserts. Hilarion as a man of reason is being emotional while Luxima is being patience on that condition. Owenson is here showing the binary opposition in between Hilarion and Luxima. John Whale agrees with this view that "... Hazlitt's skeptical empiricism resists Eastern religion as much as it does abstraction or abstruse metaphysical speculation" (p. 216). He means Britishers try to see the Eastern religion through empirical spirit from Western mind set not from the spirit of the East.

Another cause of the Missionary in failing for the converting mission according to Owenson is not due to his arrogance but the inability in understanding rightly the devotedness of Luxima 
to the Brahma. She gets Darshan from Brahma and is more committed to Hinduism. Owenson in her novel argues that:

The vision of a human countenance! If human it might be called; which gave the perfect image of Brahma, as he is represented in the Avatar of "the Destroyer". It vanished- the moon sank in clouds- the vision lasted but a moment; but that moment forever decided the fate of the priestess of Cashmire! Luxima saw no more - with a loud and piercing shriek she fell prostate on the earth. (p. 149).

Luxima, the priestess who had the opportunity of having Darshan of the God, how can she be converted into Christian. Seemingly, she appears to have been converted because she wants Hilarion as her husband but she can't be converted from her heart. Christianity to Luxima is only for erotic purpose but she is not Christian in reality. She remains Hindu ever after. The Missionary thus represents Luxima as a sort of Superwoman, embodying all the traits (and more) thought to be ideal in the Hindu woman. And this justifies that Hindus and Hinduism remain unconquerable and unconvertible. While conjuring India from colonial mindset, everything is othered: the language, geography, religion, and culture. But Owenson shows Indian culture not in Saidian notion of empire that West is good and East is bad. But rather in positive line to Hinduism. Michael J. Franklin argues that Jones had no intention of disorienting the Orient (p. 64). "By writing about the Indian knowledge and culture, Jones says that Britain should rule India in Indian way but not in British way" (Pandey Lecture).

This is all about the colonizer's arrogance that prides on his Christianity and considers
Hinduism a weaker and patience and tries his best to achieve his intention but is not succeeded finally. As the colonizer, the Christians gazed on the Cross while the Hindus gazed upon the impress of Brahma which was shining on the bosom of Luxima while dying. Sydney Owenson in her novel justifies this saying that "The Christians fixed their eyes upon the cross, which glittered on a bosom ..." (p. 259). Whereas "The Hindus gazed upon the sacred impress of Brahma, the marked on the brow of his consecrated offspring; and beheld the fancied herald of the tenth Avater..." (p. 260).

Hilarion ultimately gives up his faith, his missionary project, and his Western roots. Urging Luxima to resist her approaching death, Hilarion exclaims "Dearest and most unfortunate, our destinies are now inseparably united" (Owenson, p. 255). Although Luxima might be willing to commit sati in order to be eternally united with her lover, she will not die without renewing her commitment to Brahma; in fact she had never truly converted to Christianity. As she explains to Hilarion that "It was thou I followed, and not thy doctrines; for pure and sublime as they may be, they came darkly and confusedly to my soul..."(Owenson, p. 231). Here, this indicates that Luxima had surrendered to Hilarion on an emotional rather than a spiritual level, and significantly, that his missionary efforts have ultimately failed. Luxima's final words urge Hilarion to disseminate her story and preach religious tolerance. Instead, he returns to Kashmir and practices both Christianity and Hinduism until his own death. Hilarion's capitulation signals the failure of the missionary and civilizing projects as well as a deficit of character, of zeal, and of 
faith. Conversely, Luxima's excess, her layers of faith, love and passion, permit her to ultimately uphold her loyalty to her Hindu religion and her Catholic lover.

\section{Conclusion}

Ultimately, Owenson, in her novel The Missionary: an Indian Tale, tries to present her ideas against the religious mission of the British colonizers. The West made the sati system as the entry point for their mission by propagandizing it as a barbaric and inhumane system. Finding India and its people primeval, Hilarion determines and makes "himself master of the dialects of Upper India" (Owenson, p. 25 ), and "of the topography of the country" (Owenson, p. 47). He is now greatly selfdetermined in his mission but very soon gets frustrated as finds nobody to listen to him and finally finds Luxima as an ideal person for his mission as she is a young female on the one hand and a widow on the other. He misunderstands the woman's status in the Hindu society as being lower than that of man and also as a widow performing sati at the death of her husband. Though Hilarion presents himself as the rescuer of Luxima from sati but his reason gives way to passion. The colonizer Hilarion loses his so-called reason and subdues to passion in front of the grandeur of Luxima and Hindu religion. His mission of freeing Indian women from sati and civilizing the uncivilized Hindus remains unfulfilled and exists the binary opposition between the colonizer's arrogance where reason converts into lustful passion and the so called barbaric Eastern remains unconverted and patience. So, this is the novel of binary opposition between the arrogance of Hilarion and the patience of the priestess Luxima.

\section{About the author}

Mr. Ammai is a lecturer of Ghodaghodi Multiple Campus Sukhad, Kailali. He is an M. Ed. in English and is a student of M. Phil. English in Thesis Year. He has been involved in teaching learning activities since 2063 B.S. as an English lecturer. He has been involved in academic activities, seminars, workshops and has published some of his research articles in different journals. At present he is the head of department of Education Faculty of GMC Sukhad, Kailali.

\section{References}

Botkin, F. (2010). Burning down the [Big] House: Sati in Sydney Owenson's the Missionary: An Indiantale. Retrieved from www.colloquy. monash.edu.au/issue15/botkin.pdf

Franklin, M. J. (1998). Accessing India: Orientalism, anti- 'Indianism' and the rhetoric of Jones and Burke. Romanticism and Colonialism. New York: Cambridge University Press.

Franklin, M. J. (2006). General introduction and [meta] historical background [re] presenting the palanquins of state; or, broken leaves in a Mughal garden. Romantic representation of British India. London: Routledge.

Franklyn, M. (2006). Passion's empire: Sydney Owenson's Indian venture, phoenicianism, orientalism and binarism. Studies in Romanticism 45.2 p.181-197.

Freeman, K. (2005). Eternally disunited: Gender, empire, and epistemology in Sydney Owenson'sthe Missionary. Wordsworth Circle 36.1 p. 21-28. 
Judson, B. (2006). Under the influence: Owenson, Shelly, and the religion of dreams. Modern Philology 104.2, p. 202-223.

Owenson, S. (1811). The Missionary: An Indian tale. New York: Franklyn Company.

Pandey, B. (2014). Class Lecture. Romanticism, colonialism and representation of India. Central Department of English. T. U. Kirtipur.

Whale, J. (1998). Indian jugglers: Hazlitt, romantic orientalism and the difference of view. Romanticism and Colonialism. New York: Cambridge University Press. 